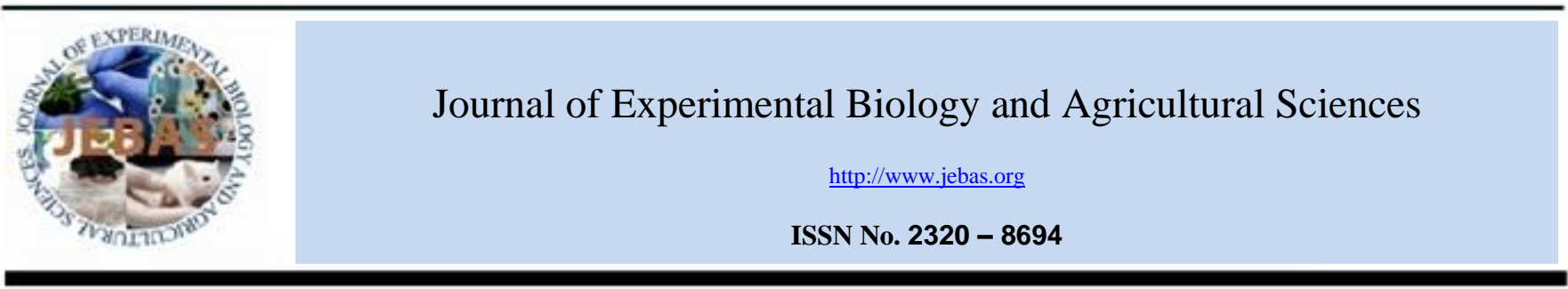

\title{
CHEMICAL INVESTIGATION AND ANTIPROLIFERATIVE STUDIES OF ISOLATED POLYISOPRENYLATED BENZOPHENONES FROM STEM-BARK OF Garcinia maingayi \\ Sangeetha Arullappan ${ }^{1 *}$, Wong Fai $\mathrm{Chu}^{2}$, Lim Chan Kiang ${ }^{3}$, Vivien Jong Yi Mian ${ }^{4}$, Sim Kooi Mow $^{5}$
}

${ }^{1}$ Department of Allied Health Sciences, Faculty of Science, Universiti Tunku Abdul Rahman, Perak Campus, Bandar Barat, Jalan Universiti, 31900 Kampar, Perak, Malaysia.

2, 3, ${ }^{5}$ Department of Chemical Science, Faculty of Science, Universiti Tunku Abdul Rahman, Perak Campus, Bandar Barat, Jalan Universiti, 31900 Kampar, Perak, Malaysia.

${ }^{4}$ Centre for Applied Sciences, Faculty of Applied Sciences, Universiti Teknologi MARA, Samarahan Campus 2, Jalan Meranek, 94300 Kota Samarahan, Sarawak, Malaysia.

Received - July 18, 2020; Revision - September 17, 2020; Accepted - October 26, 2020

Available Online - March 25, 2021

DOI: http://dx.doi.org/10.18006/2021.9(Spl-1-GCSGD_2020).S71.S84

Keywords

Garcinia maingayi

Polyisoprenylated

Benzophenones

Apoptosis

Caspases

Flow Cytometry

\begin{abstract}
In the current study, sequential solvents extraction from the stem bark of Garcinia maingayi, a native plant to Malaysia has led to the isolation of four polyisoprenylated benzophenones: 30-epi-cambogin (GB 1), 14deoxy-30-epi-cambogin (GB 2), guttiferone F (GB 3), and 14-deoxy-guttiferone F (GB 4). The structures were elucidated using IR, optical rotation, and NMR spectral data. The compounds were evaluated for antiproliferative effect using MTT assay, apoptosis using Annexin V/7-AAD flow cytometry, cell cycle progression, and activation of caspases 3/7, 8 and 9 and BCL2 mRNA expression in MCF-7, HeLa, and HepG2 cancer cell lines. Compounds GB 1 to GB 4 exhibited a remarkable antiproliferative effect on HeLa, MCF-7, and HepG2 cells with $\mathrm{IC}_{50}$ values ranging from 5 to $45 \mu \mathrm{M}$. Compounds GB 1 to GB 4 induced significant cell cycle arrest in the G1 phase corroborated with the decrease in the number of MCF7 and HepG2 cells in S and G2/M phases ( $\mathrm{P}<0.05$ ). Compounds GB 1 to GB 4 induced apoptosis at $48 \mathrm{~h}$. Further, among these, compounds GB 1 and GB 2 induced significant levels of caspases 3 and 9 in HeLa cells, while GB 3 induced caspase 9 activities in both MCF-7 and HepG2 cells. No significant induction of caspase 8 was observed suggesting that the apoptotic effects are mainly mediated through the intrinsic pathway. Only compound GB 1 inhibited the BCL2 mRNA expression significantly in all treated cancer cells. In conclusion, these compounds possess anticancer properties and thus further investigation is crucial on the mechanistic study, structure-activity relationship, and identification of putative molecular targets.
\end{abstract}

* Corresponding author

E-mail: sangeetha@utar.edu.my (Sangeetha Arullappan)

Peer review under responsibility of Journal of Experimental Biology and Agricultural Sciences.

Production and Hosting by Horizon Publisher India [HPI] (http://www.horizonpublisherindia.in/).

All rights reserved.
All the articles published by Journal of Experimental Biology and Agricultural Sciences are licensed under a Creative Commons Attribution-NonCommercial 4.0 International License Based on a work at www.jebas.org.

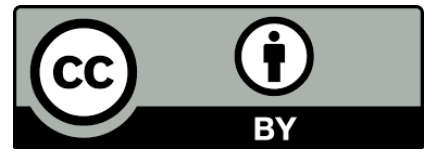




\section{Introduction}

Therapeutic uses of medicinal plants in the pharmaceutical drug discovery against cancer have been tested over the past century. World Health Organization (WHO) estimated 21.7 million people will be diagnosed with cancer and 13 million people will die because of cancer by the year 2030 (Ferlay et al., 2015). Cancer incidence rates are increasing rapidly and have become the second leading cause of death globally. In line with the drug development, the Garcinia species is one of the important plants studied greatly for medicinal values.

Garcinia is a polygamous dioecious evergreen fruit tree or shrub that belongs to Guttiferae (Clusiaceae) family (Chai, 2000; Joseph et al., 2005; Jabit et al., 2009; Hemshekhar et al., 2011). Approximately 450 species of Garcinia are widely distributed in tropical Asia, South Africa, and Polynesia as well as in Australia (Kumar et al., 2013; Patil \& Appaiah, 2015). Garcinia is widely found in Malaysia specifically in Kedah, Perak, Pahang, Terengganu, Johor (Kochummen, 1998; Jabit et al., 2009) and primarily present in Sabah and Sarawak (Repin et al., 2012; Ling \& Julia, 2012). Detailed chemical studies on Garcinia species using nuclear magnetic resonance (NMR) spectroscopy revealed the presence of triterpenoids (stigmasterol, sitosterol), benzophenone (isoxanthochymol), xanthone (1,3,7-trihydroxy-2-3(3-methylbut-2-enyl)xanthone), and benzoic acid derivative (3,4dihydroxy-methylbenzoate) (Cheng \& Cheow, 2008). The presence of phenolic compounds contributed to antioxidant properties (Krishnamoorthy et al., 2014), while xanthone and benzophenone have cytotoxic properties toward various human cancer cell lines (Kumar et al., 2013).

Two newly isolated caged xanthones from G. wightii viz., wightiic acid and 16-O-methyl wightiic acid also showed antiproliferative activities. However, the wightiic acid showed exceptional antiproliferative activity with $\mathrm{IC}_{50}$ of 4.7 and $5.2 \mu \mathrm{Min}$ A-375 and MCF-7 cells, respectively (Lekshmi et al., 2020). Garcinia xanthone I, a newly isolated xanthone from G. xanthochymus induce HepG2 apoptosis through the mitochondrial pathway and proved as a potential drug in the treatment of liver cancer (Jin et al., 2019). There is a lack of study on the Malaysian species of $G$. maingayi. The current study was carried out to reveal the effect of the pure bioactive compounds on various biological activities and their possible mechanism of action. The ability to induce apoptosis is the primary characteristic in considering the efficacy of the compound as a chemopreventive agent is shown in this research.

\section{Materials and Methods}

\subsection{Plant material}

Stem-bark of G.maingayi was collected from the forest of Semengok, Sarawak, Malaysia in June 2014. The plant was authenticated by Mr. Tinjan Anak Kuda, a botanist from the Forest Department, Sarawak. A voucher specimen of UITM 3017 was deposited at the herbarium of Universiti Teknologi MARA, Sarawak.

\subsection{Isolation and purification}

The $2.7 \mathrm{~kg}$ dried stem-bark of G.maingayi was sequentially extracted using hexane, ethyl acetate, dichlomethane, ethanol, and methanol for three days at room temperature. Each filtrate was concentrated using a rotary evaporator at 40 to $60^{\circ} \mathrm{C}$. The crude extracts were chromatographed on a silica gel (Merck) column with increasing polarity of organic solvents at various ratios. These steps were repeated successfully using gravity column chromatography and preparative thin-layer chromatography to obtain pure compounds.

\subsection{Chemical investigation}

The pure compounds were elucidated using Jeol JNM-ECX (Japan), $400 \mathrm{MHz}$ NMR spectrometer with the use of trimethylsilane (TMS) as internal and reference standards for ${ }^{1} \mathrm{H}$ $\mathrm{NMR},{ }^{13} \mathrm{C} \mathrm{NMR}$, HMQC, and HMBC spectra. IR spectra were analyzed using Fourier Transform Infrared (FTIR) (Perkin Elmer). Optical rotations were measured on Jasco Europe P-2000 digital polarimeter.

\subsection{Antiproliferative analysis \\ 2.4.1 Cancer cell lines}

Human cervical epithelial carcinoma cell line (HeLa)(ATCC $\left.{ }^{\circ} \mathrm{CCL}-2^{\mathrm{TM}}\right)$, human breast adenocarcinoma cell line (MCF-7)(ATCC®HTB-22 ${ }^{\mathrm{TM}}$ ), and human hepatocellular carcinoma cell line (HepG2)(ATCC®HB-8065 ${ }^{\mathrm{TM}}$ ) were cultured in DMEM supplemented with $10 \%$ fetal bovine serum (FBS), 100 $\mathrm{UI} / \mathrm{ml}$ penicillin and $100 \mathrm{UI} / \mathrm{ml}$ streptomycin (Sigma-Aldrich, St. Louis, MO, USA). All the cell lines were maintained at $37^{\circ} \mathrm{C}$ in a $5 \% \mathrm{CO}_{2}$ incubator.

\subsubsection{MTT assay}

The 3-(4,5-dimethylthiazol-2-yl)-2,5-diphenyltetrazolium bromide (MTT) assay as described by Leong et al. (2007) and Bradshaw et al. (2005) with some modifications was used. Cancer cell lines were seeded into 96-well plates (Nunc, Denmark) at concentrations ranging from $1 \times 10^{4}$ to $10^{5}$ cells. Compounds, DMSO, and doxorubicin hydrochloride (positive control) (Nacalai Tesque, Japan) were added into respective wells and incubated for $48 \mathrm{~h}$ at $37^{\circ} \mathrm{C}$ in $5 \% \mathrm{CO}_{2}$ incubator. MTT reagent $(5 \mathrm{mg} / \mathrm{ml})$ (Sigma, UK) was added and incubated further for $4 \mathrm{~h}$, followed by the addition 
of $100 \mu \mathrm{l}$ of DMSO. The absorbance was measured using a microplate reader (Omega, Germany) at $570 \mathrm{~nm}$. The doseresponse curves and $50 \%$ growth inhibition concentrations $\left(\mathrm{IC}_{\mathbf{5 0}}\right)$ were determined from GraphPad Prism (version 8.0.2).

\subsubsection{Flow cytometry}

Propidium iodide staining coupled with flow cytometry was used in the evaluation of cell cycle progression. The population of apoptotic cells was measured using the PE Annexin V Apoptosis Detection Kit (BD Biosciences, San Jose, CA, USA) according to the manufacturer's instructions. Both floating and attached cells were collected, stained, and analyzed using a FACS Calibur flow cytometer and the CellQuest Pro software (version 5.1.1; BD Biosciences, USA) (BD Biosciences, 2008).

\subsubsection{Caspases activation}

The catalytic activity of caspases $3 / 7,8$, and 9 was measured at 48 $\mathrm{h}$ after treatment using Caspase-Glo 3/7, Caspase-Glo 8, and Caspase-Glo 9 assay kits (Promega, Madison, WI, USA) based on manufacturer's guidelines (Promega, 2018).

\subsubsection{BCL2 mRNA expression}

Treated cancer cell lines were further preceded to RNA extraction and the cDNA was synthesized using high capacity RNA-to-cDNA master mix based on manufacturers' protocol(Qiagen, Valencia, CA, USA; Applied Biosystems, Carlsbad, California, USA) (Qiagen, 2013). FastStart Universal SYBR green master reagent (Roche, Indianapolis, USA) and Bio-Rad iQ5 real-time PCR detector system (Bio-Rad, Richmond, CA, USA) (Pabla \& Pabla, 2008) were used. Bio-Rad iQ5 Optical System Software V1.0 was used for data analysis. Table 1 shows primer sequences used in the expression. The 40 cycle's conditions were $3 \mathrm{~min}$ at $94^{\circ} \mathrm{C}$ followed by $40 \mathrm{~s}$ at $94^{\circ} \mathrm{C}, 40 \mathrm{~s}$ at $60^{\circ} \mathrm{C}$, and $25 \mathrm{~s}$ at $72^{\circ} \mathrm{C}$. The housekeeping gene, GAPDH was used in the normalization (Reboucas et al., 2013).

\subsection{Data analysis}

Data were reported as mean \pm standard deviation from a minimum of three independent experiments. Levels of significance were determined using student t-test, whereas treatments were compared to the control. $\mathrm{P}<0.05$ was considered statistically significant unless otherwise specified.

\section{Results and Discussion}

\subsection{Structural elucidation}

The 30-epi-cambogin (GB 1), 14-deoxy-30-epi-cambogin (GB 2), guttiferone F (GB 3) and 14-deoxy-guttiferone F (GB 4) were isolated from G. maingayi (Figure 1).Table 2 summarizes the

Journal of Experimental Biology and Agricultural Sciences http://www.jebas.org detail of compounds, while Table 3 shows the ${ }^{1} \mathrm{HNMR}$ and ${ }^{13}$ CNMR spectra of the compounds GB 1 to GB 4 . The molecular formula of GB 1 was $\mathrm{C}_{38} \mathrm{H}_{50} \mathrm{O}_{6}$ with the mass of 602 and optical rotation $([\alpha] \mathrm{D})$ of $-129^{\circ}$. The molecular formula of GB 2 was $\mathrm{C}_{38} \mathrm{H}_{50} \mathrm{O}_{6}$ differing from GB 1 by an oxygen atom. Compounds GB 1 and GB2 were different on the aromatic ring in which GB 1 has two $\mathrm{OH}$ groups at $\mathrm{C} 13$ and $\mathrm{C} 14$, while GB 2 has only one $\mathrm{OH}$ group at $\mathrm{C} 13$. The molecular formula of GB 3 is similar to that of GB 1 with $\mathrm{C}_{38} \mathrm{H}_{50} \mathrm{O}_{6}$, while the molecular formula of $\mathrm{GB} 4$ is similar to that of GB 2 .

The NMR spectra of GB 4 were generally similar to that of GB 3 except for the absence of an $\mathrm{OH}$ group at $\mathrm{C} 14$ which was replaced by an aromatic proton. Compounds GB 1 and GB 2 were obtained as a yellow powder, while compounds GB 3 and GB 4 as yellow and honey consistency.

Compounds GB 1 and GB 3 were also reported obtained from the root wood of Allanblackia stuhlmannii (Engl.) in the early phase of research (Fuller et al., 1999) with the same structural properties. However, compounds GB 2 and GB 4 obtained in this study are new compounds and reported isolated for the first time from Malaysian species of G. maingayi.

\subsection{Antiproliferative effect}

Figure 2 shows the dose-response curves of cancer cell lines treated with various concentrations of compounds GB 1 to GB 4 for $48 \mathrm{~h}$. These compounds exhibited cytotoxicity with $\mathrm{IC}_{50}$ values in the range of 5 to $45 \mu \mathrm{M}$ as shown in Table 4 . The number of cells reduced drastically upon treatment as compared to vehicle control (0.1\% DMSO) indicating cytotoxic effect (Figure 3).

The monolayer cells detached and form spherical shapes revealing death mode upon treatment. The original anchorage-dependent cancer cells losses their adhesiveness or lose their substrate attachment and becomes rounded, further shrinks due to cell death (Freshney, 2005; Kleinsmith, 2006). These morphological changes confirm the presence of anticancer properties in the isolated compounds that act as mitogen factors.

Visible cell death suspensions upon treatment were seen in HeLa cells as compared to other cells. Kenji et al. (2003) reported garcinol, isogarcinol and xanthochymol from $G$. purpurea displayed a strong apoptosis-inducing effect against human leukemia cell lines namely NB4, HL60, U937, and K-562 via nuclear fragmentation and DNA ladder formation. Kai-Wei et al. (2012) reported garcinielliptones S and phloroglucinol from G. subelliptica remarkably increased the cell death of human bladder carcinoma cells (NTUB1) at $72 \mathrm{~h}$ with IC $_{50}$ values of $45.1 \pm 7.8,13.5 \pm 2.3$ and $3.3 \pm 0.1 \mu \mathrm{M}$, respectively. These studies were in agreement with the current study supporting that the compounds isolated from G. Maingayi are potential antiproliferative agents. 


\subsection{Cell cycle progression}

The effects of compounds GB 1 to GB 4 in MCF-7 and Hep G2 on cell cycle progression is shown in Figure 4. These compounds induced significant cell cycle arrest in $\mathbf{G 1}$ phase corroborated with the decrease in the number of cells in $\mathrm{S}$ and $\mathrm{G} 2 / \mathrm{M}$ phases $(\mathrm{P}<0.05)$. Due to excessive cell death, cell cycle analysis was not able to perform on HeLa cells. The link between apoptosis and cell cycle progression in cancer cells is considered a possibly effective approach to control tumour growth (Roger \& Mike, 2006). A classic cell cycle progression is represented by early-G1, late-G1, $\mathrm{S}$, and G2/M phases. Higher G1 populations were seen in both MCF-7 and HepG2 treated cells, and this causes a concomitant decrease in the population of cells in the $\mathrm{G} 2 / \mathrm{M}$ phase as compared to control. The results showed the G1 cell cycle arrest induces cell death in the cancer cell lines. The current study agrees with Zhang et al. (2016) that a novel compound nujiangexathone A from $G$. nujiangensis suppressed HeLa by arresting the cells at G0/G1 phases from 61.65 to $73.65 \%$ and decreased the cells in the G2/M phases from 23.55 to $12.60 \%$ after 48 hours at $20 \mu \mathrm{M}$.

\subsection{Induction of apoptosis}

Compounds GB 1 to GB 4 induced apoptosis in all the cancer cell lines by a significant percentage of apoptosis following treatment for $48 \mathrm{~h}$ using Annexin V/7-AAD staining. Compounds GB 1 and GB 2 exhibited the highest percentage of apoptosis in HeLa cells, while the lowest was shown by compound GB 2 in HepG2 cells. However, $0.1 \%$ of DMSO as vehicle control showed a lower apoptotic rate indication the cells are viable. Figure 5 shows the scatter plots of the treated cancer cells entering to first early apoptotic stage and finally to the late apoptotic stage. It is seen that lesser treated cells enter the necrotic stage (upper left).

\subsection{Activation of Caspases}

Caspases 3/7, 8, and 9 activities in HeLa, MCF-7 and HepG2 activation following treatment exhibited a remarkable apoptotic effect (Figure 6).

Table 1 Primer sequences for qPCR

\begin{tabular}{ccc} 
Gene & Forward primer & Reverse primer \\
& 5'-ATCGCCCTGTGGATGACTGAGT-3' & 5'-GCCAGGAGAAATCAAACAGAGGC-'3 \\
\hline BCL2 & 5'-GTCTCCTCTGACTTCAACAGCG-3' & 5'-ACCACCCTGTTGCTGTAGCCAA-3' \\
\hline
\end{tabular}

Table 2 Summarised details of the isolated polyisoprenylated benzophenones from the stem-bark of G. maingayi

\begin{tabular}{|c|c|c|c|c|}
\hline Features & GB 1 & GB 2 & GB 3 & GB 4 \\
\hline Findings & Known compound & New compound & Known compound & New compound \\
\hline $\begin{array}{c}\text { Isolated from Crude } \\
\text { extracts }\end{array}$ & Methanol & Dichloromethane & $\begin{array}{c}\text { The mixture of ethanolic } \\
\text { and hexane }\end{array}$ & Ethyl acetate \\
\hline Name & 30-epi-cambogin & $\begin{array}{l}\text { 14-deoxy-30-epi- } \\
\text { cambogin }\end{array}$ & Guttiferone F & 14-deoxy-guttiferone $\mathrm{F}$ \\
\hline Form & Yellow powder & Yellow powder & $\begin{array}{l}\text { Yellow and honey } \\
\text { consistency }\end{array}$ & $\begin{array}{l}\text { Yellow, honey } \\
\text { consistency }\end{array}$ \\
\hline Molecular formula & $\mathrm{C}_{38} \mathrm{H}_{50} \mathrm{O}_{6}$ & $\mathrm{C}_{38} \mathrm{H}_{50} \mathrm{O}_{5}$ & $\mathrm{C}_{38} \mathrm{H}_{50} \mathrm{O}_{6}$ & $\mathrm{C}_{38} \mathrm{H}_{50} \mathrm{O}_{5}$ \\
\hline Molecular mass & 602 & 586 & 602 & 586 \\
\hline Optical rotation & $-129^{\circ}$ & $-143^{\circ}$ & $-298^{\circ}$ & $-255^{\circ}$ \\
\hline
\end{tabular}


Table $3{ }^{1} \mathrm{H}$ NMR and ${ }^{13} \mathrm{C}$ NMR spectra of compounds GB 1 to GB 4

\begin{tabular}{|c|c|c|c|c|c|c|c|c|}
\hline Position & GB 1 & $\begin{array}{l}\text { GB } 2 \\
\delta \mathrm{C}, \mathrm{ppm}\end{array}$ & GB 3 & GB 4 & GB 1 & $\begin{array}{l}\text { GB } 2 \\
\delta \mathrm{H}, \mathrm{ppm} \text { (type }\end{array}$ & GB 3 & GB 4 \\
\hline 1 & 171.7 & 171.9 & 199.0 & 198.5 & - & - & - & - \\
\hline 2 & 125.2 & 125.2 & 116.0 & 116.5 & - & - & - & - \\
\hline 3 & 194.6 & 193.9 & 193.9 & 193.6 & - & - & - & - \\
\hline 4 & 68.2 & 68.3 & 69.8 & 69.9 & - & - & - & - \\
\hline 5 & 46.1 & 46.4 & 49.7 & 49.8 & - & - & - & - \\
\hline 6 & 46.2 & 46.4 & 46.9 & 46.8 & $1.33, \mathrm{~m}$ & $1.45, \mathrm{~m}$ & $1.45, \mathrm{~m}$ & $1.41, \mathrm{~m}$ \\
\hline 7 & 39.3 & 39.7 & 42.7 & 42.7 & $\begin{array}{c}1.86, \mathrm{dd}(14.6,7.3) \\
2.14, \mathrm{~d}(14.6)\end{array}$ & $\begin{array}{l}1.98, \mathrm{dd}(14.2, \\
7.3) 2.28, \mathrm{~d} \\
(14.2)\end{array}$ & $\begin{array}{c}2.03, \mathrm{~m} \\
2.35, \mathrm{~d} \\
(14.2)\end{array}$ & $\begin{array}{c}2.04, \mathrm{~m} \\
2.35, \mathrm{~d}(13.8)\end{array}$ \\
\hline 8 & 51.2 & 51.3 & 58.0 & 57.9 & - & - & - & - \\
\hline 9 & 207.3 & 207.4 & 209.3 & 209.3 & - & - & - & - \\
\hline 10 & 193.2 & 193.7 & 195.0 & 195.4 & - & - & - & - \\
\hline 11 & 129.9 & 133.2 & 127.8 & 132.1 & - & - & - & - \\
\hline 12 & 114.3 & 114.8 & 116.5 & 115.8 & $7.21, \mathrm{~d}(1.8)$ & $7.29, \mathrm{t}(1.4)$ & $6.91, \mathrm{~m}$ & $6.87, \mathrm{~m}$ \\
\hline 13 & 144.7 & 156.2 & 143.8 & 156.1 & - & - & - & - \\
\hline 14 & 150.6 & 121.7 & 149.9 & 121.2 & - & $\begin{array}{c}7.14, \mathrm{dt}(7.8, \\
1.4) \\
\end{array}$ & - & $6.90, \mathrm{~m}$ \\
\hline 15 & 114.4 & 129.7 & 114.4 & 128.9 & $6.61, \mathrm{~d}(7.9)$ & $7.18, \mathrm{t}(7.8)$ & $6.58, \mathrm{~d}(8.0)$ & $7.10, \mathrm{t}(7.8)$ \\
\hline 16 & 123.8 & 120.6 & 124.2 & 120.1 & $6.87, \mathrm{dd}(7.9,1.8)$ & $\begin{array}{c}6.96, \mathrm{dt}(7.8, \\
1.4)\end{array}$ & $6.93, \mathrm{~m}$ & $6.85, \mathrm{~m}$ \\
\hline 17 & 25.5 & 25.7 & 27.1 & 26.3 & $\begin{array}{l}2.30, \text { dd }(13.7,5.2) \\
2.54, \text { dd }(13.7,5.5)\end{array}$ & $\begin{array}{l}2.43, \text { dd }(13.7,5.5 \\
2.64, \text { dd }(13.7,8.2\end{array}$ & $\begin{array}{c}2.72, \mathrm{~m} \\
2.58, \mathrm{~d} \\
(12.4)\end{array}$ & $\begin{array}{c}2.71, \mathrm{~m} \\
2.52, \mathrm{~d}(13.7)\end{array}$ \\
\hline 18 & 119.6 & 119.9 & 120.2 & 120.0 & $4.77, \mathrm{~m}$ & $4.90, \mathrm{t}(5.5)$ & $5.08, \mathrm{~m}$ & - \\
\hline 19 & 134.6 & 139.0 & 135.4 & 137.7 & - & - & - & $5.08, \mathrm{~m}$ \\
\hline 20 & 25.9 & 26.2 & 26.2 & 26.2 & $1.47, \mathrm{~s}$ & $1.58, \mathrm{~s}$ & $1.79, \mathrm{~s}$ & $1.78, \mathrm{~s}$ \\
\hline 21 & 17.9 & 18.1 & 18.3 & 18.1 & $1.45, \mathrm{~s}$ & $1.57, \mathrm{~s}$ & $1.73, \mathrm{~s}$ & $1.68, \mathrm{~s}$ \\
\hline 22 & 22.3 & 22.6 & 22.8 & 22.7 & $1.03, \mathrm{~s}$ & $1.15, \mathrm{~s}$ & $1.15, \mathrm{~s}$ & $1.11, \mathrm{~s}$ \\
\hline 23 & 26.6 & 26.9 & 26.5 & 27.1 & $0.85, \mathrm{~s}$ & $0.97, \mathrm{~s}$ & $1.00, \mathrm{~s}$ & $0.99, \mathrm{~s}$ \\
\hline 24 & 29.2 & 29.4 & 29.0 & 29.1 & $\begin{array}{l}2.03, \mathrm{~m} \\
2.49, \mathrm{~m}\end{array}$ & $\begin{array}{l}2.15, \mathrm{~m} \\
2.59, \mathrm{~m} \\
\end{array}$ & $\begin{array}{l}2.05, \mathrm{~m} \\
2.10, \mathrm{~m} \\
\end{array}$ & $\begin{array}{l}2.02, \mathrm{~m} \\
2.09, \mathrm{~m}\end{array}$ \\
\hline 25 & 124.8 & 125.0 & 123.9 & 123.9 & $4.77, \mathrm{~m}$ & $4.90, \mathrm{t}(5.5)$ & $4.92, \mathrm{t} 7.3)$ & $4.90, \mathrm{~m}$ \\
\hline 26 & 133.0 & 133.8 & 133.1 & 133.0 & - & - & - & - \\
\hline 27 & 25.8 & 26.0 & 25.8 & 25.9 & $1.54, \mathrm{~s}$ & $1.66, \mathrm{~s}$ & $1.65, \mathrm{~s}$ & $1.67, \mathrm{~s}$ \\
\hline 28 & 17.9 & 18.0 & 18.1 & 18.0 & $1.56, \mathrm{~s}$ & $1.65, \mathrm{~s}$ & $1.52, \mathrm{~s}$ & $1.51, \mathrm{~s}$ \\
\hline 29 & 28.3 & 28.4 & 36.3 & 36.2 & $\begin{array}{c}0.84, \mathrm{~m} 2.91, \mathrm{dd} \\
(14.0,3.7)\end{array}$ & $\begin{array}{c}0.93, \mathrm{~m} \mathrm{3.03, \textrm {dd }} \\
(14.2,3.7)\end{array}$ & $\begin{array}{c}1.98, \mathrm{~m} \\
1.88, \mathrm{dd} \\
(14.0,4.2) \\
\end{array}$ & $\begin{array}{l}1.90, \mathrm{~m} \\
1.93, \mathrm{~m}\end{array}$ \\
\hline 30 & 42.8 & 42.9 & 43.7 & 43.6 & $1.28, \mathrm{~m}$ & $1.39, \mathrm{~m}$ & $2.67, \mathrm{~m}$ & $2.74, \mathrm{~m}$ \\
\hline 31 & 86.7 & 86.7 & 148.1 & 148.2 & - & - & - & - \\
\hline 32 & 28.5 & 28.6 & 112.8 & 17.8 & $0.78, \mathrm{~s}$ & $0.88, \mathrm{~s}$ & $\begin{array}{l}4.36, \mathrm{~s} \\
4.40, \mathrm{~s} \\
\end{array}$ & $1.60, \mathrm{~s}$ \\
\hline 33 & 21.1 & 21.3 & 18.0 & 112.7 & $1.12, \mathrm{~s}$ & $1.23, \mathrm{~s}$ & $1.59, \mathrm{~s}$ & $\begin{array}{l}4.40, \mathrm{~s} \\
4.43, \mathrm{~s} \\
\end{array}$ \\
\hline 34 & 29.6 & 29.7 & 32.7 & 32.7 & $\begin{array}{l}1.67, \mathrm{~m} \\
1.91, \mathrm{~m} \\
\end{array}$ & $\begin{array}{l}1.79, \mathrm{~m} \\
2.02, \mathrm{~m} \\
\end{array}$ & $2.03, \mathrm{~m}$ & $\begin{array}{l}2.00, \mathrm{~m} \\
2.12, \mathrm{~m}\end{array}$ \\
\hline 35 & 121.3 & 121.5 & 122.7 & 122.7 & $5.07, \mathrm{t}(7.3)$ & $5.15, \operatorname{td} 6.6,1.4)$ & $5.03, \mathrm{t} 6.8)$ & $5.04, \mathrm{~m}$ \\
\hline 36 & 133.7 & 134.7 & 132.1 & 135.1 & - & - & - & - \\
\hline 37 & 25.6 & 25.9 & 25.9 & 25.8 & $1.65, \mathrm{~s}$ & $1.74, \mathrm{~s}$ & $1.69, \mathrm{~s}$ & $1.67, \mathrm{~s}$ \\
\hline 38 & 18.0 & 18.2 & 18.1 & 18.2 & $1.48, \mathrm{~s}$ & $1.60, \mathrm{~s}$ & $1.54, \mathrm{~s}$ & $1.54, \mathrm{~s}$ \\
\hline
\end{tabular}

*Recorded at $400 \mathrm{MHz}$ for ${ }^{1} \mathrm{H}$ NMR, $100 \mathrm{MHz}$ for ${ }^{13} \mathrm{C}$ NMR in $\delta \mathrm{ppm}$ : assignments based on DEPT, HMCQ and HMBC [s singlet, $\mathrm{m}$ multiplet, d doublet, dd doublet of doublet, $\mathrm{t}$ triplet] 
Table 4 In vitro cytotoxic effect of compounds GB 1 to GB 4 as expressed in $\mathrm{IC}_{50}$ values at $48 \mathrm{~h}$

\begin{tabular}{lccc} 
Sample & & IC $\mathbf{5 0}$ values $(\boldsymbol{\mu M})$ & HepG2 \\
& HeLa & MCF-7 & \\
\hline GB 1 & & & $8.02 \pm 1.53$ \\
\hline GB 2 & $13.24 \pm 1.53$ & $5.48 \pm 0.20$ & $9.25 \pm 1.57$ \\
\hline GB 3 & $15.49 \pm 1.39$ & $5.30 \pm 0.32$ & $18.03 \pm 1.99$ \\
& & & \\
\hline GB 4 & $33.71 \pm 2.33$ & $12.46 \pm 0.57$ & $24.97 \pm 1.04$ \\
& & & $0.45 \pm 0.01$
\end{tabular}

Compounds GB 1 and GB 2 induced significant (>two-fold induction and $\mathrm{P}<0.01$ by student $\mathrm{t}$-test) levels of caspases $3 / 7$ and 9 activities in HeLa cells, while compound GB 3 induces caspase 9 activities in both MCF-7 and HepG2 cells. Compound GB 4 is the least potent among all the compounds tested, as apoptosis was only detected in MCF-7 and HepG2 cells. Compound GB 4 induces significant caspase 9 activation suggesting activation of the intrinsic pathway.

Interestingly, compound GB 4 did not induce caspases $3 / 7$, 8, or 9 activities in HepG2 cells despite a significant induction of apoptosis suggesting that the compound might induce cell death through a caspase-independent mechanism. No induction of caspase 8 was observed suggesting that the apoptotic effects induced by compounds GB 1 to GB $\mathbf{4}$ are mainly mediated through the intrinsic apoptotic pathway. Activation of the $\mathrm{Bcl} 2$ protein family usually occurs in response to DNA damage via the mitochondrial pathway (Damagoj \& Wayne, 2007).

Similarly, Ahmed et al. (2012) and Sethi et al. (2014) reported garcinol from the fruit rind of $G$. indica killed prostate (LNCaP, C4-2B and PC3) and pancreatic ca(BxPC-3) cancer cells by downregulating NF-kB and phosphoinositide 3- kinase $(\mathrm{PI} 3 \mathrm{~K}) /$ serine/threonine-specific protein kinase (Akt) signaling pathways. Besides, Xiong et al. (2014) cytochrome c (Crompton, 2000). This process will further induce cell death selectively and eliminates tumour cells.

\subsection{BCL2 mRNA expression}

Results given in figure 7 shows compound GB 1 inhibited BCL2 mRNA expression significantly $(\mathrm{P}<0.01)$ in $\mathrm{HeLa}, \mathrm{MCF}-7$, and
HepG2 cells, while no such inhibitory effect was observed in other compounds treated cells.

The levels of BCL expression was reduced by $3.5,3.2$, and 1.8fold in HeLa, MCF-7, and HepG2 cells, respectively. Bcl2 family of proteins is an anti-apoptotic marker and central regulators of mitochondrial cell-intrinsic apoptotic which is directly related to apoptosis induction. The results clearly shown that the BCL2 are down-regulated in all the cancer cells treated with compound GB 1. The BCL2 itself can bind to pro-apoptotic members such as Bax and thus releases cytochrome c (Crompton, 2000). This process will further induce cell death selectively and eliminates tumour cells.

\section{Conclusion}

In a nutshell, compounds GB 1 to GB $\mathbf{4}$ induced not only cell cycle arrest but also apoptosis in cancer cell lines in a dosage-dependent manner. However, only compound GB 1 inhibited the BCL2 mRNA expression. Further investigation on the mechanistic study, chemical modification, structure-activity relationship, and identification putative molecular target of compounds GB 1 to GB 4 through in silico molecular docking can be considered.

\section{Acknowledgements}

The authors would like to thank Universiti Tunku Abdul Rahman (UTAR), Perak Campus for the financial support to complete the research.

\section{Conflicts of Interest}

The authors declare no conflict of interest. 

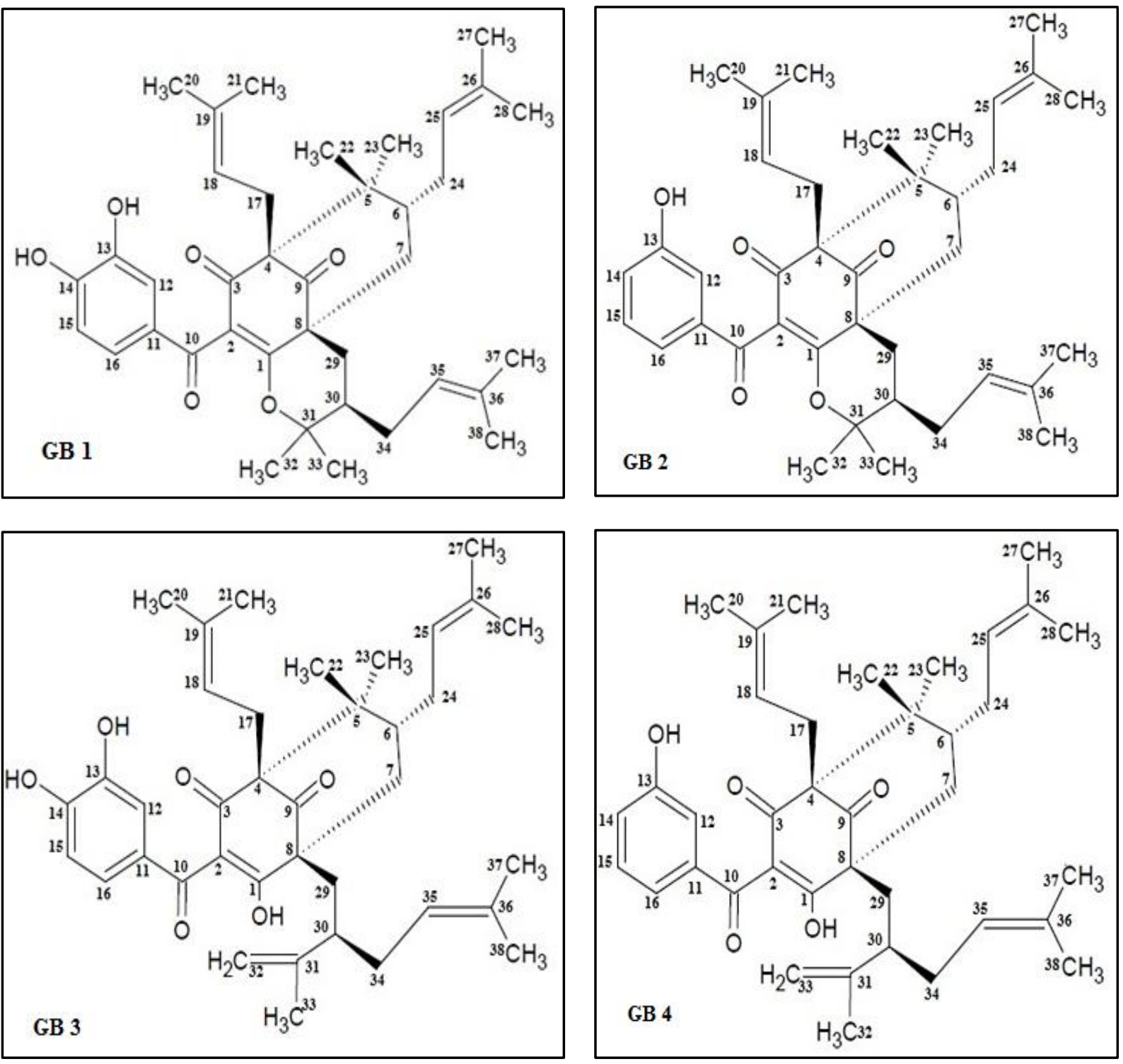

Figure 1 Chemical structures of 30-epi-cambogin (GB 1), 14-deoxy-30-epi-cambogin (GB 2), guttiferone F (GB 3) and 14-deoxy-guttiferone F (GB 4) 

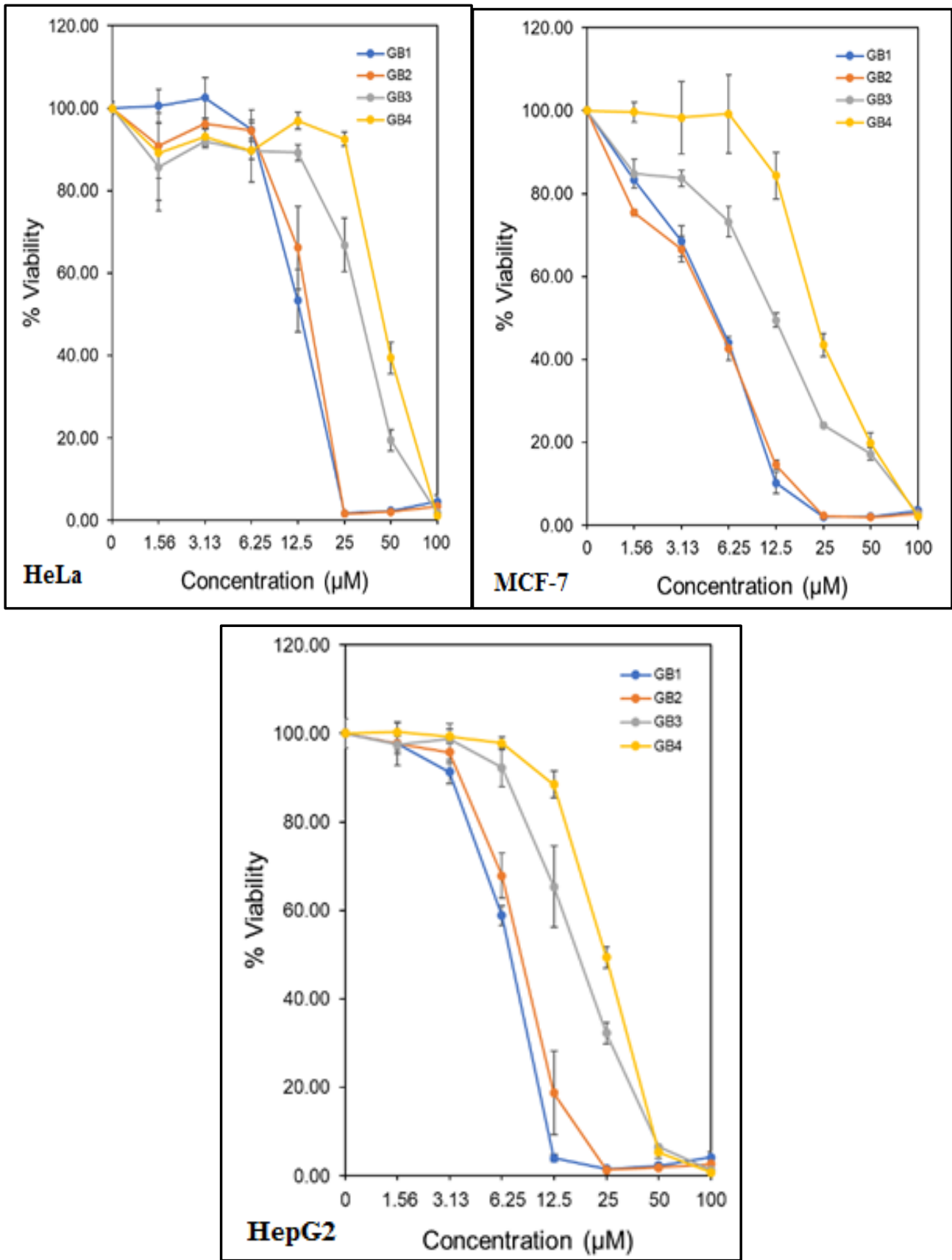

Figure 2 The antiproliferative effect in HeLa, MCF-7 and HepG2 cancer cell lines treated with compounds

GB 1 to GB 4 at $48 \mathrm{~h}$. The points represent means \pm standard deviation $(\mathrm{n}=3)$ 

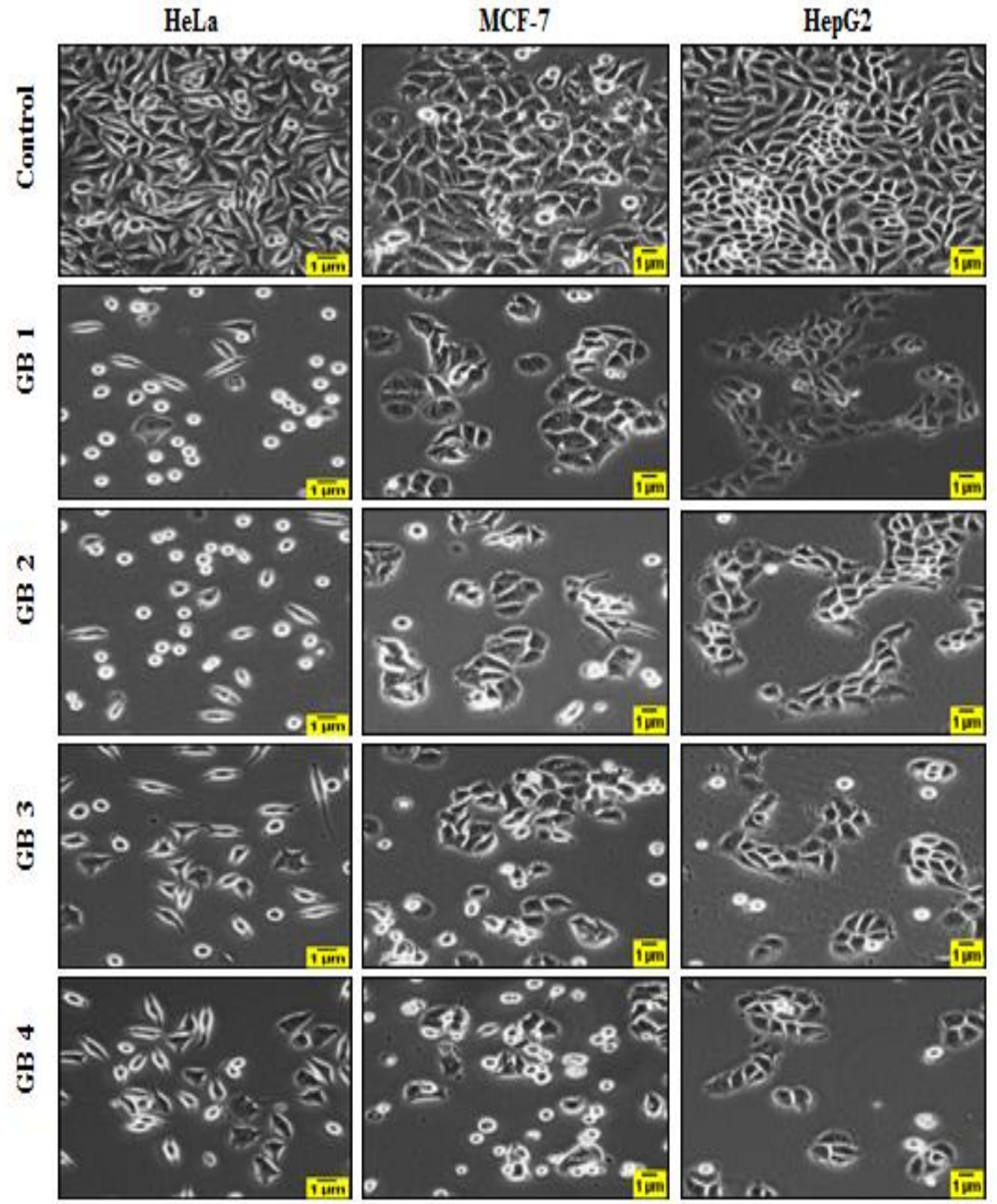

Figure 3 Morphological changes in MCF-7, HeLa and HepG2 cells induced by compounds GB 1 to GB 4 and $0.1 \%$ DMSO (vehicle control) using microscopy analysis (100x)

Journal of Experimental Biology and Agricultural Sciences http://www.jebas.org 
$\underline{\text { MCF-7 }}$
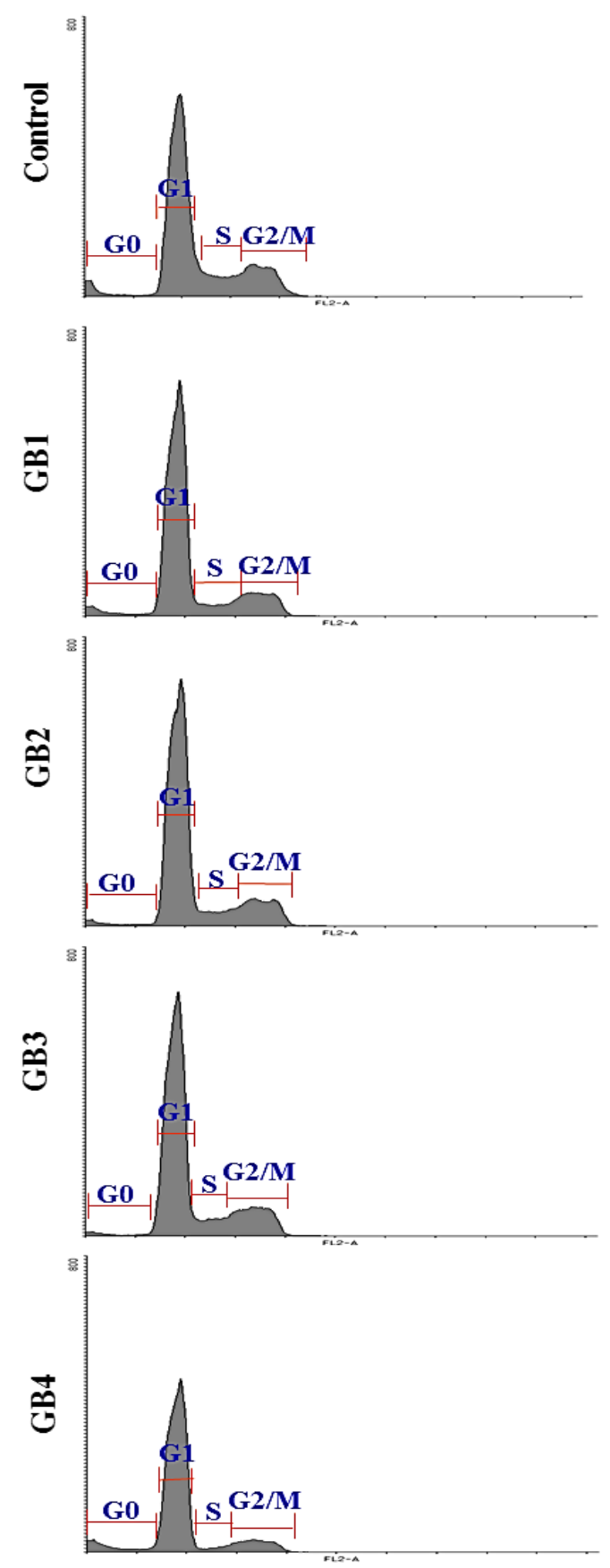

HepG2
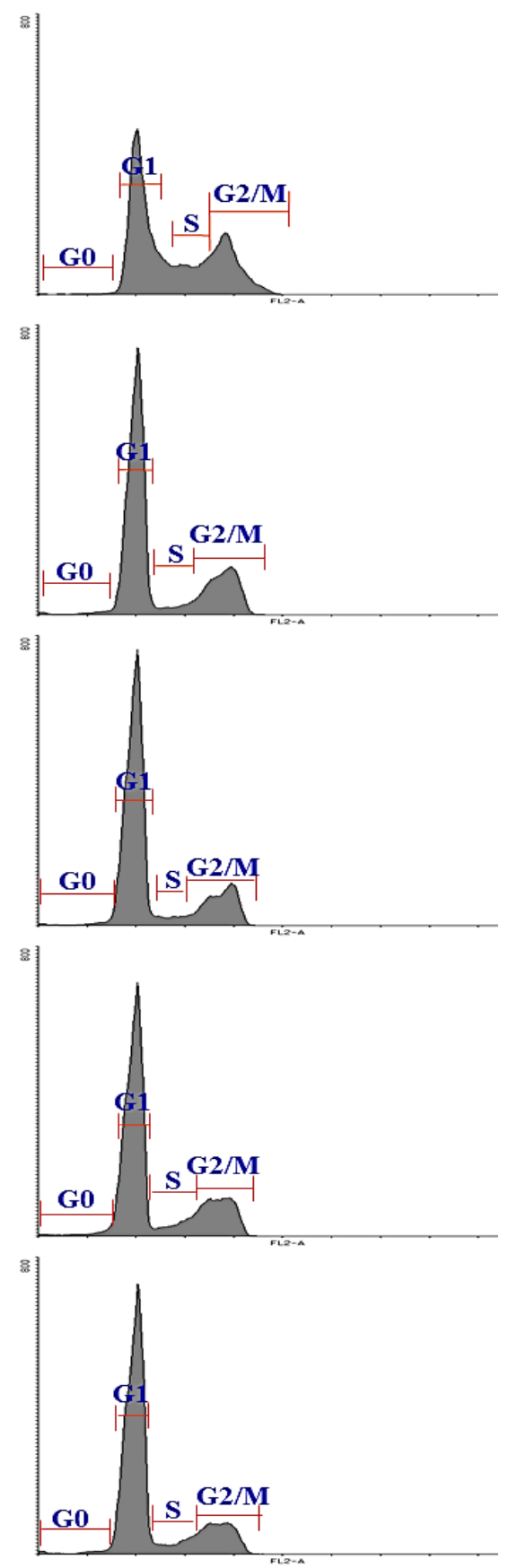

|Figure 4 Cell cycle arrests induced by compounds GB 1 to GB 4 in MCF-7 and HepG2 cellsat 48 h, followed by propidium staining and flow cytometry

Journal of Experimental Biology and Agricultural Sciences http://www.jebas.org 


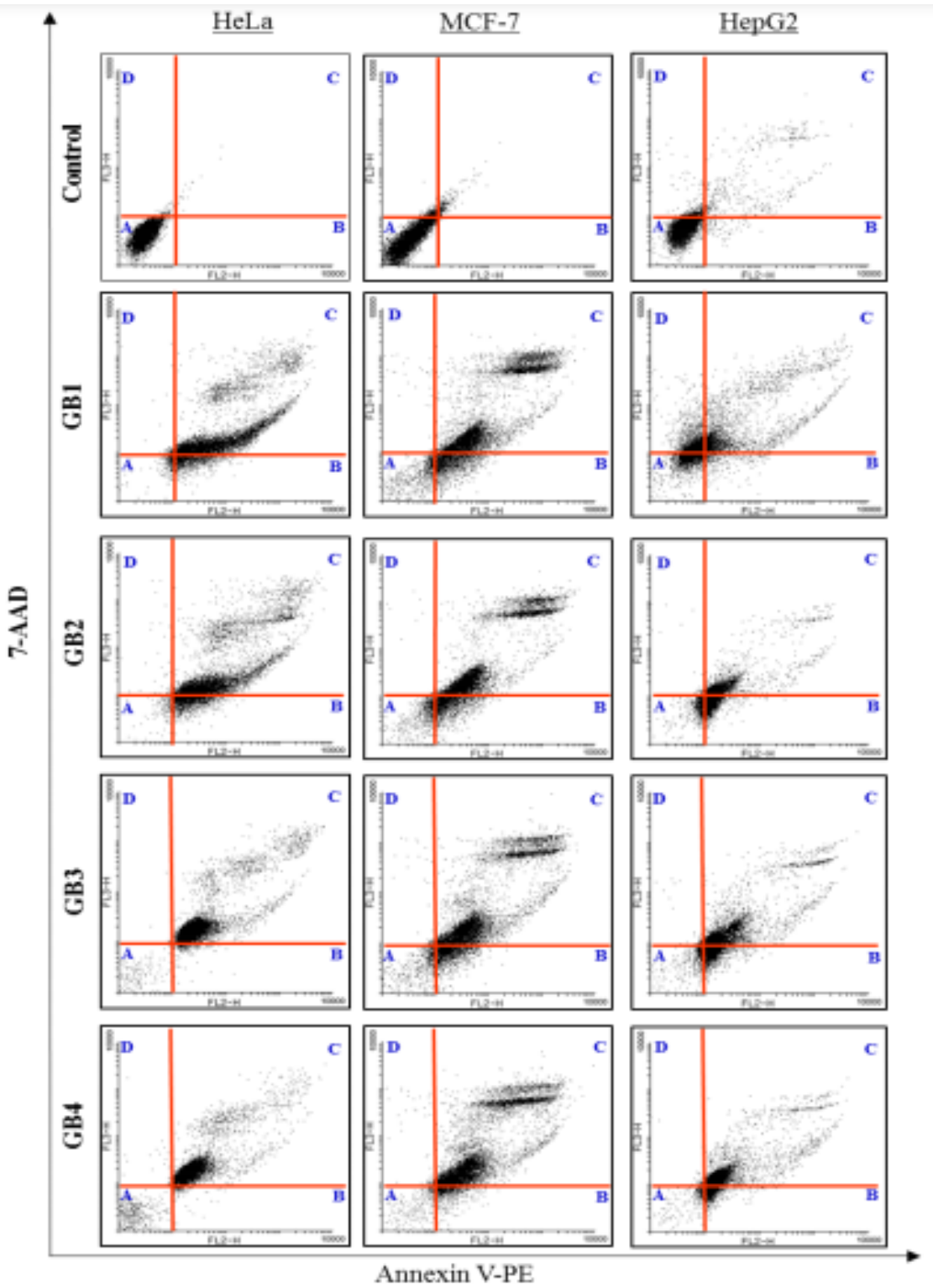

Figure 5 Flow cytometric PE Annexin-V/7-ADD binding profiles of MCF-7, HeLa and HepG2 cancer cell lines treated with $0.1 \%$ DMSO (vehicle control) and compounds GB 1 to GB 4 at $48 \mathrm{~h}$. Regions labelled A indicating viable cells, B is early apoptotic cells, $\mathrm{C}$ is late apoptotic cells and D is necrotic cells 


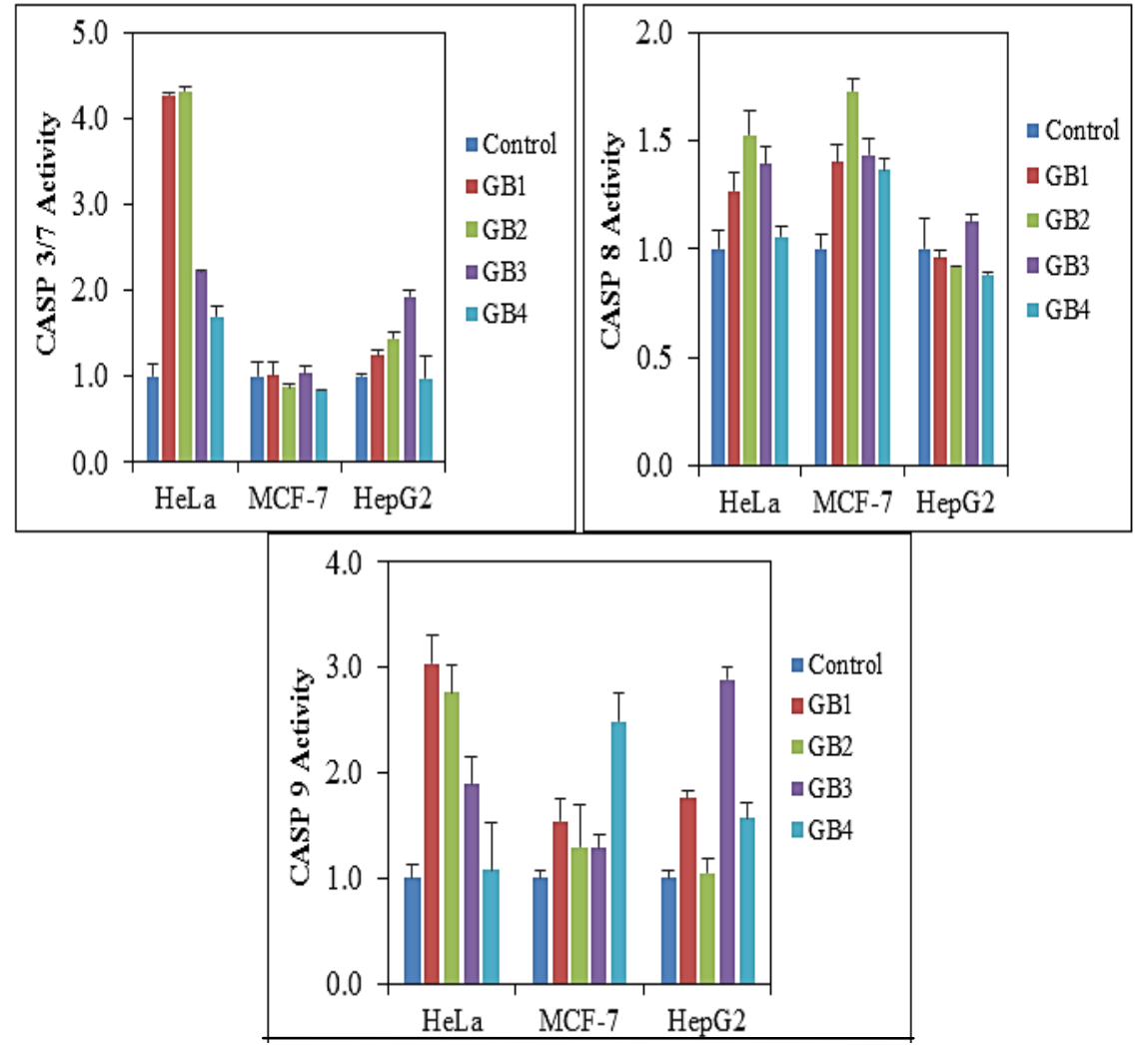

Figure 6 Effects of compounds GB 1 to GB 4 on caspases 3/7, 8 and 9 activities in HeLa, MCF-7 and HepG2 cells. The bars represent the mean \pm standard deviation $(\mathrm{n}=3)$ and $*$ indicates fold change $>2$ and $\mathrm{P}<0.05$ (Student $\mathrm{t}$-test)

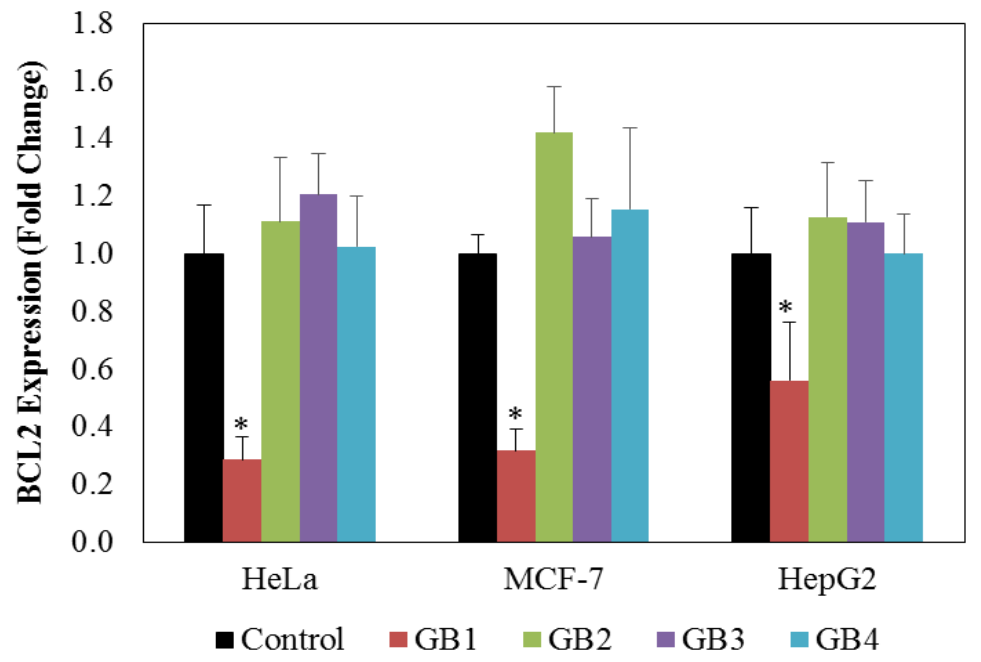

Figure 7 BCL2 mRNA expression profile in MCF-7, HeLa and HepG2 cancer cell lines treated with compounds GB 1 to GB 4 at 48 h. Bars indicate mean \pm standard deviation $(n=3)$. * indicates $P<0.01$, Student t-test 


\section{REFERENCES}

Ahmad A, Sarkar SH, Aboukameel A, Ali S, Biersack B, Seibt S, Li Y, Bao B, Kong D, Banerjee S, Schobert R, Padhye SB, Sarkar FH (2012) Anticancer action of garcinol in vitro and in vivo is in part mediated through inhibition of STAT-3 signalling. Carcinogenesis 33(12): 2450-2456. doi: 10.1093/carcin/bgs290.

BD Biosciences (2008) Technical data sheet: PE annexin V apoptosis detection kit[Online]. Available at: http://www.bdbiosciences.com/ds/pm/tds/559763.pdf Accessed: 17 December 2018.

Bradshaw TD, Matthews CS, Cookson J, Chew EH, Shah M, Bailey K, Monks A, Harris E, Westwell AD, Wells G, Laughton CA, Stevens MFG (2005) Elucidation of thioredoxin as a molecular target for antitumor quinols. Cancer Research 65(9): 3911-3919.

Chai PK (2000) A check-list of flora, fauna, food and medicinal plants, Yokohama-City, Japan: International Tropical Timber Organization and Sarawak, Malaysia, Sarawak Forest Department.

Cheng GLE, Cheow YL (2008) Secondary metabolites from two Garcinia species and their biological activities. Chemistry: An Asian Journal 20(1): 343-351.

Crompton M (2000) Bax, Bid and the permeabilization of the mitochondrial outer membrane in apoptosis. Journal of Biological Chemistry 280(46): 38271-38275.

Domagoj V, Wayne JF (2007) The inhibitor of apoptosis proteins as therapeutic targets in cancer. Clinical Cancer Research 13(20): 5995-6000.

Ferlay JI, Soerjomataram R, Dikshit S, Eser C, Mathers M, Rebelo DM et al. (2015) Cancer incidence and mortality worldwide: Sources, methods and major patterns in Globocan 2012. International Journal of Cancer 136(5): 359-386.

Freshney RI (2005) Culture of animal cells: A manual of basic techniques (5th Eds), John Wiley \& Sons, Inc., New Jersey. Fuller RW, Blunt JW, Boswell JL, Cardellina JH, Boyd MR (1999) Guttiferone F, the first prenylated benzophenone from Allanblackia stuhlmannii. Journal of Natural Products 62(1):130132.

Hemshekhar M, Sunitha K, Santhosh MS, Devaraja S, Kemparaju K, Vishwanath BS, Niranjana SR, et al (2011) An overview on genus Garcinia: Phytochemical and therapeutic aspects. Phytochemical Review 10: 325-351.

Jabit ML, Wahyuni FS, Khalid R, Israf DA, Shaari K, Lajis NH, et al. (2009) Cytotoxic and nitric oxide inhibitory activities of methanol extracts of Garcinia species. Pharmaceutical Biology 47(11): 1019-1026.
Jin S, Shi K, Liu L, Chen Y, Yang G (2019) Xanthones from the bark of Garcinia xanthochymus and the mechanism of induced apoptosis in human hepatocellular carcinoma HepG2 cells via the mitochondrial pathway. International Journal of Molecular Sciences 20(19): 4803.

Joseph GS, Jayaprakasha GK, Selvi AT, Jena BS, Sakariah KK (2005) Antiflatoxigenic and antioxidant activities of Garcinia extracts. International Journal of Food Microbiology 101: 153-160.

Kai-Wei L, A-Mei H, Shyh-Chyun Y, Jing-Ru W, Tzyh-Chyuan H, Yeong-Shiau P, Chun-Nan L (2012) Cytotoxic and antioxidant constituents from Garcinia subelliptica. Food Chemistry135: 851859 .

Kenji M, Akao Y, Kobayashi E, Ito T, Ohguchi K, Tanaka T, Iinuma M, Nozawa Y (2003) Cytotoxic benzophenone derivatives from Garcinia species displays a strong apoptosis-inducing effect against human leukaemia cell lines. Biological and Pharmaceutical Bulletin 26(4):569-571.

Kleinsmith LJ (2006) Principles of cancer biology. San Francisco, Pearson International Edition.

Kochummen KM (1998) Garcinia maingayi [Online]. Available at: http://www.iucnredlist.org/details/37830/0 [Accessed: 14 January 2016].

Krishnamoorthy V, Nagappan P,Sereen AK, Rajendran R (2014) Preliminary phytochemical screening of the fruit rind of Garcinia cambogia and leaves of Bauhinia variegate: A comparative study. International Journal of Current Microbiology and Applied Sciences 3(5): 479-486.

Kumar S, Sharma S, Chattopadhyay K (2013) The potential health benefit of polyisoprenylated benzophenones from Garcinia and related genera: Ethnobotanical and therapeutic importance. Fitoterapia 89: 86-125.

Lekshmi NM, Kavya Satheesh SK, Sreejith PP, Rameshkumar KB (2020) Antiproliferative activity of caged xanthones from the leaves of Garcinia wightii T.Anderson. Filoterapia 143: 104592.

Leong CO, Vidnovic N, DeYoung MP, Sgroi D, Ellisen LW (2007) The p63/p73 network mediates chemo-sensitivity to cisplatin in a biologically defined subset of primary breast cancers. Journal of Clinical Investigation 117(5): 1370-1380.

Ling CY, Julia S (2012) Diversity of the tree flora in Semenggoh Arboretum, Sarawak, Borneo. Gardens' Bulletin Singapore 64(1): 139-169.

Pabla SS, Pabla SS (2008) Real-time polymerase chain reaction: A revolution in diagnostics. Resonance 13: 369-377. 
Patil MM, Appaiah KAA (2015) Garcinia: Bioactive compounds and health benefits. Introduction to Functional Food Science 4: 110-125.

Promega (2018) Cell health assays [Online]. Available at:http://www.promega.com/CellHealth [Accessed 3: December 2018].

Qiagen (2013) RNA isolation and purification from cell lines[Online].

Available

at:http://compbio.dfci.harvard.edu/compbio/research/labprotocols/ contentBlocks/0/contentBlock_files/file16/RNA_Isolation_and_Pu rification_from_Cell_Lines_Using_Qiagen.pdf [Accessed: 18 December 2018].

Reboucas EDL, Costa JJDN, Passos MJ, Passos JRDS, Hurk RVD, Silva JRV (2013) Real time PCR and importance of housekeeping genes for normalization and quantification of mRNA expression in different tissues. Brazilian Archives of Biology and Technology 56(1): 143-154.
Repin R, Majuakim L, Suleiman M, Nilus R, Mujih H, Gunsalam G (2012) Checklist of trees in Crocker Range Park Permanent Research Plot, Sabah, Malaysia. Journal of Tropical Biology and Conservation 9(1): 127-141.

Roger JBK, Mike WR (2006) Cancer Biology (3rd Ed). England, Pearson Education Limited.

Sethi G Chatterjee S, Rajendran P, Li F, Shanmugam MK, Wong KF, Kumar AP, Senapati P, Behera AK, Hui KM, Basha J, Natesh N, Luk JM, Kundu TK (2014) Inhibition of STAT3 dimerization and acetylation by garcinol suppresses the growth of human hepatocellular carcinoma in vitro and in vivo. Molecular Cancer 13: 66 .

Xiong S, Mu T, Wang G, Jiang X (2014) Mitochondria-mediated apoptosis in mammals. Protein and Cell 5(10): 737-749.

Zhang L, Feng J, Kong S, Wu M, Xi Z, Zhang B, Fu W, Lao Y, Tan H, Xu H (2016) Nujiangexathone A, a novel compound from Garcinia nujiangensis, suppresses cervical cancer growth by targeting hnRNPK. Cancer Letters 380: 447-456. 